\title{
Polyphasic characterization of xanthomonads pathogenic to members of the Anacardiaceae and their relatedness to species of Xanthomonas
}

\author{
Correspondence \\ O. Pruvost \\ olivier.pruvost@cirad.fr
}

\author{
N. Ah-You, ${ }^{1}$ L. Gagnevin, ${ }^{1}$ P. A. D. Grimont, ${ }^{2}$ S. Brisse, ${ }^{2}$ X. Nesme, ${ }^{3}$ \\ F. Chiroleu, ${ }^{1}$ L. Bui Thi Ngoc, ${ }^{1}$ E. Jouen, ${ }^{1}$ P. Lefeuvre, ${ }^{1}$ C. Vernière ${ }^{1}$ \\ and O. Pruvost ${ }^{1}$
}
${ }^{1}$ CIRAD, UMR Peuplements Végétaux et Bioagresseurs en Milieu Tropical CIRAD-Université de la Réunion, Pôle de Protection des Plantes, 7 chemin de l'Irat, 97410 Saint Pierre, La Réunion, France
${ }^{2}$ Unité Biodiversité des Bactéries Pathogènes Emergentes, Institut Pasteur, 25-28 rue du Dr Roux, 75724 Paris Cedex 15, France
${ }^{3}$ Ecologie Microbienne, UMR CNRS 5557/USC INRA 1193, Université Claude Bernard-Lyon 1, Villeurbanne, France

\begin{abstract}
We have used amplified fragment length polymorphism (AFLP), multilocus sequence analysis (MLSA) and DNA-DNA hybridization for genotypic classification of Xanthomonas pathovars associated with the plant family Anacardiaceae. AFLP and MLSA results showed congruent phylogenetic relationships of the pathovar mangiferaeindicae (responsible for mango bacterial canker) with strains of Xanthomonas axonopodis subgroup 9.5. This subgroup includes $X$. axonopodis pv. citri (synonym Xanthomonas citri). Similarly, the pathovar anacardii, which causes cashew bacterial spot in Brazil, was included in $X$. axonopodis subgroup 9.6 (synonym Xanthomonas fuscans). Based on the thermal stability of DNA reassociation, consistent with the AFLP and MLSA data, the two pathovars share a level of similarity consistent with their being members of the same species. The recent proposal to elevate $X$. axonopodis pv. citri to species level as $X$. citri is supported by our data. Therefore, the causal agents of mango bacterial canker and cashew bacterial spot should be classified as pathovars of $X$. citri, namely $X$. citri pv. mangiferaeindicae (pathotype strain CFBP 1716) and $X$. citri pv. anacardii (pathotype strain CFBP 2913), respectively. Xanthomonas fuscans should be considered to be a later heterotypic synonym of Xanthomonas citri.
\end{abstract}

\section{INTRODUCTION}

Abbreviations: AFLP, amplified fragment length polymorphism; CBS, cashew bacterial spot; DDH, DNA-DNA hybridization; EGD, evolutionary genome divergence; $\mathrm{MBC}$, mango bacterial canker; $\mathrm{ML}$, maximumlikelihood; MLSA, multilocus sequence analysis; NJ, neighbour-joining; nsps, nucleotide substitutions per site; rep-PCR, repetitive extragenic palindromic PCR.

The GenBank/EMBL/DDBJ accession numbers for the partial $16 \mathrm{~S}$ rRNA gene sequences of $X$. citri pv. mangiferaeindicae CFBP 1716, $X$. citri pv. anacardii CFBP 2913 and $X$. axonopodis pv. spondiae CFBP 2547 are respectively EF989732, EF989733 and EF989734. Those of the partial sequences used in the MLSA study are EU015124EU015156, EU015158-EU015215 and EU333904-EU333906 (atpD), EU015216-EU015248, EU015250-EU015307 and EU333907-EU333909 (dnaK) and EU015308-EU015340, EU015342-EU015399 and EU333910-EU333912 (gyrB).

Details of strains and primers and $\mathrm{ML}$ trees derived from partial atpD, $d n a K$ and gyrB sequences are available as supplementary material with the online version of this paper.
Mango bacterial canker (MBC) (also called mango bacterial black spot) is one of the most important bacterial diseases for mango (Mangifera indica L.) industries worldwide (Gagnevin \& Pruvost, 2001). MBC was first described in 1915 in South Africa (Doidge, 1915) but may have originated in India, as the disease was observed in herbarium specimens collected in Bihar in 1881 (Patel et al., 1948a, b). The causal agent of MBC was first reported as 'Bacillus mangiferae' (Doidge, 1915) and, in 1948, was designated 'Pseudomonas mangiferae-indicae' (Patel et al., $1948 \mathrm{a}$, b). In the 1970s, the pathogen was named Xanthomonas campestris pv. mangiferaeindicae (Robbs et al., 1974), in compliance with the international standards for naming pathovars of phytopathogenic bacteria of the International Society for Plant Pathology (Dye et al., 1980). 
Some species of the plant-pathogenic genus Xanthomonas are subdivided into pathovars. The pathovar classification established by Dye et al. (1980) and reviewed by Young et al. (1992) is an infrasubspecific classification applied to bacterial plant pathogens by reference to their host range or to their capacity to cause distinctive symptoms. Pathogenicity tests are an essential part of this classification. Pathovar nomenclature is not covered by the International Code of Nomenclature of Prokaryotes (hitherto the International Code of Bacteria; Lapage et al., 1992), but provides for the orderly reporting of bacterial plant pathogens, for scientific and technical reporting, for plant protection regulation and for quarantine (Young et al., 1992).

In 1995, reclassification of the genus Xanthomonas by a polyphasic approach including DNA-DNA hybridization (DDH) assigned strains into 20 genomospecies (Vauterin et al., 1995). More recent results have increased the number of genomospecies to 27 (Jones et al., 2004, 2006; Schaad et al., 2006; Trébaol et al., 2000), but many pathovars, including pathogens of major economic importance such as pv. mangiferaeindicae, have not been investigated. Studies based on $16 \mathrm{~S}$ rRNA gene sequences showed that several genomospecies, as determined by $\mathrm{DDH}$, shared more than $99 \%$ sequence identity, making this technique inadequate for species differentiation in the genus Xanthomonas (Hauben et al., 1997; Moore et al., 1997). Rademaker et al. (2000) showed that amplified fragment length polymorphism (AFLP) analysis and repetitive extragenic palindromic PCR (rep-PCR) data positively correlated with DDH. These two genotyping techniques can be used for routine species identification and can be included in a polyphasic scheme for describing novel species or combinations (Rademaker et al., 2005; Roumagnac et al., 2004; Stackebrandt et al., 2002).

One of the Xanthomonas genomospecies, Xanthomonas axonopodis, displayed a higher intraspecific heterogeneity based on DDH as well as AFLP and rep-PCR data, and six genetic clusters were described within this species (Rademaker et al., 2000, 2005). Some members of these genetic clusters have been elevated to species rank (Xanthomonas euvesicatoria, X. perforans, X. alfalfae, X. citri and X. fuscans) (Jones et al., 2004, 2006; Schaad et al., $2005,2006,2007)$. These assignments were based on a polyphasic approach including DDH experiments using the nuclease S1 procedure (Crosa et al., 1973) performed at $T_{\mathrm{m}}-15{ }^{\circ} \mathrm{C}$.

DDH may be considered the gold standard method for genotypic delineation of bacterial species (Wayne et al., 1987). AFLP, a technique also recommended for bacterial taxonomy (Stackebrandt et al., 2002), has the advantage of generating a large number of randomly located markers over the whole genome. AFLP was useful for evaluating the species status of several genera (Aabenhus et al., 2005; Hong et al., 2005; Huys et al., 2000; Leal-Klevezas et al., 2005; Mougel et al., 2002; On et al., 2003; Thompson et al.,
2003), including xanthomonads (Janssen et al., 1996; Rademaker et al., 2000; Roumagnac et al., 2004; Boudon et al., 2005; Schaad et al., 2005). Based on AFLP data, evolutionary genome divergences (EGD) or current genome mispairing (CGM) provide a measurement of genetic divergences between genomes (Mougel et al., 2002). Recently, multilocus sequence analysis (MLSA), based on sequence analysis of several housekeeping genes, has been developed for species delineation (Gevers et al., 2005; Hanage et al., 2005a, b; Richter et al., 2006; Chelo et al., 2007; Martens et al., 2007). MLSA has the advantage of analysing phylogenetic relationships of large sets of strains with a better portability than genotyping techniques such as AFLP.

The purpose of this study was to perform a detailed genetic characterization, based on DDH, AFLP and MLSA, of the pathovar mangiferaeindicae sensu Dye et al. (1980) and to evaluate its relatedness to different Xanthomonas species. We show that the causal agent of MBC is genetically related to $X$. citri (syn. X. axonopodis group 9.5). Our data support the elevation of $X$. axonopodis pv. citri as $X$. citri and show that the causal agents of MBC and cashew bacterial spot (CBS) should be classified as pathovars of this genomospecies, namely X. citri pv. mangiferaeindicae and X. citri pv. anacardii, respectively.

\section{METHODS}

Bacterial strains and media. Xanthomonas strains isolated from members of several plant genera within the family Anacardiaceae, the type strains of 27 Xanthomonas species (Jones et al., 2004; Schaad et al., 2006; Trébaol et al., 2000; Vauterin et al., 1995) and some additional Xanthomonas axonopodis pathovars were used in this study (Supplementary Table S1, available in IJSEM Online). Some strains included in this study were deposited in the Collection Française de Bactéries Phytopathogènes (CFBP, INRA Angers, France), the BCCM/ LMG (Belgian Coordinated Collections, University of Ghent, Belgium) and the National Collection of Plant Pathogenic Bacteria (NCPPB, CSL, York, UK). Cultures were stored after lyophilization and/or in a $-80{ }^{\circ} \mathrm{C}$ freezer. They were checked for purity and routinely cultivated on YPGA $\left(1^{-1}: 7 \mathrm{~g}\right.$ yeast extract, $7 \mathrm{~g}$ peptone, $7 \mathrm{~g}$ glucose, $18 \mathrm{~g}$ agar, $20 \mathrm{mg}$ propiconazole; $\mathrm{pH} \mathrm{7.2)}$ at $28^{\circ} \mathrm{C}$, except for Xanthomonas populi strains, which were grown at $19{ }^{\circ} \mathrm{C}$. Strains that grew poorly on YPGA were cultivated on modified Wilbrink medium (Rott et al., 1988).

AFLP analysis. Genomic DNA was extracted from bacteria using the DNeasy tissue kit (Qiagen) following the manufacturer's instructions and DNA concentrations were estimated by fluorimetry (TKO 100 fluorometer; Hoefer). AFLP experiments were performed in 96-well plates in a GeneAmp PCR system 9700 thermocycler (Applied Biosystems), as described previously (Ah-You et al., 2007). Digestions were carried out in a $25 \mu \mathrm{l}$ volume for $1 \mathrm{~h}$ at $37^{\circ} \mathrm{C}$ and contained $100 \mathrm{ng}$ bacterial genomic DNA, $10 \mathrm{U}$ SacI, 2 U MspI (New England Biolabs) and $1 \times$ BSA in $1 \times$ reaction buffer NEB 1 . Next, $2.5 \mu \mathrm{l}$ of the digested products was added to $22.5 \mu \mathrm{l}$ of a ligation mixture containing $2 \mu \mathrm{M} \mathrm{MspI}$ adaptor (Supplementary Table S2), $0.2 \mu \mathrm{M}$ SacI adaptor (Supplementary Table S2) (Applied Biosystems) and $2 \mathrm{U}$ T4 DNA ligase (New England Biolabs) in $1 \times$ T4 DNA ligation buffer. Ligations were performed for $3 \mathrm{~h}$ at $37{ }^{\circ} \mathrm{C}$ before enzyme inactivation at $65{ }^{\circ} \mathrm{C}$ for $10 \mathrm{~min}$. Ligation products were diluted 10 -fold with 
HPLC-grade water before preselective PCR. The reactions were done in $15 \mu \mathrm{l}$ and contained $5 \mu \mathrm{l}$ diluted ligation product, $2.5 \mathrm{mM} \mathrm{MgCl}$, $0.23 \mu \mathrm{M}$ each of the MspI and SacI primers (Supplementary Table S2), $0.45 \mathrm{mM}$ of each dNTP (New England Biolabs) and 0.5 U Taq DNA polymerase (Goldstar Red; Eurogentec) in $1 \times$ Goldstar buffer. The following PCR conditions were used: initial extension to ligate the second strand of the adaptors at $72{ }^{\circ} \mathrm{C}$ for $2 \mathrm{~min}$, a denaturation step at $94{ }^{\circ} \mathrm{C}$ for $2 \mathrm{~min}, 25$ cycles at $94{ }^{\circ} \mathrm{C}$ for $30 \mathrm{~s}, 56{ }^{\circ} \mathrm{C}$ for $30 \mathrm{~s}$ and $72{ }^{\circ} \mathrm{C}$ for $2 \mathrm{~min}$ and a final extension step at $72{ }^{\circ} \mathrm{C}$ for $10 \mathrm{~min}$. PCR products were diluted 10 -fold with HPLC-grade water before selective amplification.

Selective amplifications using the unlabelled $M s p \mathrm{I}+\mathrm{A}, \mathrm{C}, \mathrm{T}$ or $\mathrm{G}$ primer and the labelled $\mathrm{SacI}+\mathrm{C}$ primer (with four different fluorochromes) (Supplementary Table S2) were performed under the same conditions as the preselective PCR except that the SacI +C primer concentration was $0.12 \mu \mathrm{M}$. The following PCR conditions were used: initial denaturation at $94{ }^{\circ} \mathrm{C}$ for $2 \mathrm{~min}$ followed by 37 cycles at $94{ }^{\circ} \mathrm{C}$ for $30 \mathrm{~s}$, annealing for $30 \mathrm{~s}$ at $65{ }^{\circ} \mathrm{C}$ for the first cycle, decreased by $0.7{ }^{\circ} \mathrm{C}$ per cycle for the next 12 cycles and then $56{ }^{\circ} \mathrm{C}$ for the last 24 cycles and extension at $72{ }^{\circ} \mathrm{C}$ for $2 \mathrm{~min}$, with a final extension step at $72{ }^{\circ} \mathrm{C}$ for $10 \mathrm{~min}$. Samples were then prepared for capillary electrophoresis by adding $1 \mu \mathrm{l}$ of the final PCR product to $18.7 \mu \mathrm{l}$ formamide and $0.3 \mu \mathrm{l}$ LIZ500 DNA ladder (Applied Biosystems) as an internal standard. The mixture was then denatured for $5 \mathrm{~min}$ at $95{ }^{\circ} \mathrm{C}$ and placed on ice for at least $5 \mathrm{~min}$. Electrophoresis was performed in an ABI Prism 3100 Genetic Analyzer (Applied Biosystems) using performance-optimized polymer POP-4 at $15000 \mathrm{~V}$ for about $20 \mathrm{~min}$ at $60^{\circ} \mathrm{C}$, with an initial injection of $66 \mathrm{~s}$. AFLP fingerprints were analysed visually using GENESCAN software 3.7 (Applied Biosystems). To test the reproducibility of the AFLP technique, two independent DNA extractions were used for all strains, and strain 306 of X. citri pv. citri (Da Silva et al., 2002) was used as a control in each AFLP experiment.

The presence and absence of fragments were scored as a binary matrix. The threshold for assigning a peak was set to 200 relative fluorescence units. EGD were calculated from Dice similarity indices and corrected to account for unobserved substitutions by using the standard Jukes-Cantor model, which assumes equal rates of substitution between all pairs of bases (Mougel et al., 2002; Portier et al., 2006). EGD values were used as distances to construct a weighted neighbour-joining (NJ) tree (Gascuel, 1997; Saitou \& Nei, 1987) using the $\mathrm{R}$ software (version 2.3.1; R Development Core Team). The robustness of the tree was assessed by bootstrap (1000 resamplings).

Gene amplification and sequencing. Amplification of $16 \mathrm{~S}$ rRNA genes was performed by PCR in $50 \mu \mathrm{l}$ reaction mixtures using the BD Advantage 2 polymerase mix kit (Clontech), as recommended by the manufacturer, for strains CFBP 1716, CFBP 2913 and CFBP 2547 (pathotype strains for pv. mangiferaeindicae, anacardii and spondiae, respectively) (Ah-You et al., 2007). The specific primers were FGPS6 $\left(5^{\prime}\right.$-GGAGAGTTAGATCTTGGCTCAG-3') and FGPS1509 (5'AAGGAGGGGATCCAGCCGCA-3'), described by Nesme et al. (1995), which complement bases 6-27 and bases 1522-1541 (Escherichia coli 16S rRNA gene sequence numbering), respectively. PCRs were performed in a PE9600 thermocycler (Applied Biosystems). The amplification program included denaturation at $95{ }^{\circ} \mathrm{C}$ for $3 \mathrm{~min}, 35$ cycles of denaturation at $95{ }^{\circ} \mathrm{C}$ for $1 \mathrm{~min}$, annealing at $55{ }^{\circ} \mathrm{C}$ for $1 \mathrm{~min}$ and extension to $72{ }^{\circ} \mathrm{C}$ for $2 \mathrm{~min}$ and a final extension step at $72{ }^{\circ} \mathrm{C}$ for $3 \mathrm{~min}$. Amplified fragments were purified using a QIAquick PCR purification kit (Qiagen) and cloned into the pGEM-T easy plasmid (Promega) as recommended by the manufacturer. Sequence data were obtained by primer-walking double-strand analysis (Sequencia) using primers T7 and SP6, which flank the cloning region in the pGEM-T easy plasmid. Internal primers were 16SU579 (5'-ACTCCACCGCTTGTGC-3'), 16SU1124 (5'-CGCGGCATGGCTGGAT-3'), 16SL573 (5'-GCGGTGGAGTATGTGG-3') and 16SL1169 (5' - ACGGGAGGCAGCAGTG-3'). Sequence data were compared to those of other xanthomonads (Hauben et al., 1997; Roumagnac et al., 2004; Trébaol et al., 2000) by alignment using the CLUSTAL_X software (Thompson et al., 1997). Comparisons were based on a partial sequence of $1475 \mathrm{bp}$, corresponding to the shortest region published for a Xanthomonas type strain (i.e. GenBank accession no. X95922 from X. populi LMG $5743^{\mathrm{T}}$ ).

Gene portions of $d n a K$ (encoding the $70 \mathrm{kDa}$ heat-shock protein; Hsp70), atpD ( $\mathrm{F}_{1}-\mathrm{F}_{0}$ ATPase subunit) and gyrB (DNA gyrase beta subunit) (Table 1) were amplified by PCR in $50 \mu \mathrm{l}$ reaction mixtures using the BD Advantage 2 polymerase mix kit (Clontech), as recommended by the manufacturer. PCRs were performed in a PE9600 thermocycler as follows: heating to $95{ }^{\circ} \mathrm{C}$ for $3 \mathrm{~min}$ and 35 cycles of denaturation for $1 \mathrm{~min}$ at $95{ }^{\circ} \mathrm{C}$, annealing for $1 \mathrm{~min}$ at $66{ }^{\circ} \mathrm{C}$ and extension to $68{ }^{\circ} \mathrm{C}$ for $1 \mathrm{~min}$, followed by a final extension step at $68{ }^{\circ} \mathrm{C}$ for $7 \mathrm{~min}$. For a small number of strain-gene combinations, the annealing temperature was modified $\left(63-68{ }^{\circ} \mathrm{C}\right)$ for optimal PCR quality or yield. The PCR products were sequenced by Macrogen. The dnaK, atpD and $g y r B$ sequences from Stenotrophomonas maltophilia K279a (http://www.sanger.ac.uk/ Projects/S_maltophilia/) were used as outgroups.

Phylogenetic analyses of housekeeping genes. DNA sequences for each gene ( na $a$, atpD and $g y r B$ ) were aligned using the CLUSTAL W-based subalignment tool (Thompson et al., 1997) available in MEGA 3.1 program (Kumar et al., 2004). Tajima's D (Tajima, 1989), which tests the hypothesis that observed mutations are selectively neutral by measuring differences between the population mutation rate and the mean number of nucleotide differences, was performed for each gene portion using DnaSP, version 4.0 (Rozas et al., 2003). The method of Nei \& Gojobori (1986) was used to evaluate nonsynonymous/synonymous substitution ratios $\left(K_{\mathrm{a}} / K_{\mathrm{s}}\right)$ using Swaap software version 1.0.2 (http://www.bacteriamuseum.org/SWAAP/ SwaapPage.htm). Nucleotide and amino acid sequence identities and transition/transversion ratios were also evaluated using Swaap software. Detection of potential recombinant sequences, identification of likely parental sequences and localization of possible recombination breakpoints were carried out on a concatenated sequence alignment using the rdp, geneconv, bootscan, maximum chi-squared, chimaera and sister scan recombination detection methods as implemented in the RDP3 software (Martin et al., 2005). The analysis was performed with default settings for the different detection methods and a Bonferroni-corrected $P$-value cutoff of 0.05 . Recombination events were accepted when detected with three detection methods or more. The breakpoint positions and recombinant sequence(s) inferred for every detected potential recombination event were checked visually and adjusted where necessary by using the extensive phylogenetic and recombination signal analysis features available in RDP3.

Maximum-likelihood (ML) trees were calculated for each of the three genes by using PAUP* (version 4.0b10). The Shimodaira-Hasegawa (S-H) method (Shimodaira \& Hasegawa, 1999), as implemented in PAUP*, was used to test whether the tree topologies based on each locus fall within the same confidence limits.

Phylogenetic analyses including NJ and ML trees of the alignment of concatenated genes were conducted both in PAUP* and in PHYML (Guindon \& Gascuel, 2003). The model of substitution was chosen using the $\mathrm{R}$ software and the APE package implemented in R (Paradis, 2006) and PHYML. Bootstrap analyses were done with 1000 replicates for NJ and ML. For the Bayesian approach, MrBayes software (version 3.1.2) (Huelsenbeck \& Ronquist, 2001) was used. Two runs with four Markov chains (using default heating values) consisting of $7.0 \times 10^{6}$ generations starting from a random initial tree were run simulta- 
Table 1. Genetic relatedness between xanthomonads pathogenic to members of the Anacardiaceae and selected type strains

Data marked AFLP are EGD values (Mougel et al., 2002) based on four combined AFLP conditions. The mean EGD value (derived from AFLP) among 15 strains of pathovar mangiferaeindicae was $0.010 \mathrm{nsps}(\mathrm{SD}=0.0029)$. The mean EGD value among four strains of pathovar anacardii was 0.016 nsps $(\mathrm{SD}=0.0093)$. Data marked MLSA are genetic distances based on the evolution model GTR $+\Gamma+\mathrm{I}$, based on concatenated sequences (Paradis, 2006). PT, Pathotype strain.

\begin{tabular}{|c|c|c|c|c|c|c|c|}
\hline \multirow[t]{2}{*}{ Strain } & \multirow[t]{2}{*}{ Pathovar } & \multicolumn{2}{|c|}{$X$. axonopodis LMG $982^{\mathrm{T}}$} & \multicolumn{2}{|c|}{$X$. citri LMG $9322^{\mathrm{T}}$} & \multicolumn{2}{|c|}{ X. fuscans LMG $826^{\mathrm{T}}$} \\
\hline & & AFLP & MLSA & AFLP & MLSA & AFLP & MLSA \\
\hline LA100 & anacardii & 0.1340 & 0.0422 & 0.0667 & 0.0223 & 0.0422 & 0.0041 \\
\hline CFBP $1716^{\mathrm{PT}}$ & mangiferaeindicae & 0.1530 & 0.0411 & 0.0463 & 0.0027 & 0.0770 & 0.0202 \\
\hline JN570 & mangiferaeindicae & 0.1516 & 0.0411 & 0.0495 & 0.0027 & 0.0787 & 0.0202 \\
\hline CFBP $2547^{\mathrm{PT}}$ & spondiae & 0.1194 & 0.0432 & 0.1088 & 0.0423 & 0.1056 & 0.0462 \\
\hline CFBP 2623 & spondiae & 0.1175 & 0.0432 & 0.1050 & 0.0423 & 0.0996 & 0.0462 \\
\hline
\end{tabular}

neously and sampled every 100 generations. Variations in the ML scores in these samples were examined graphically using the Tracer software (http://evolve.zoo.ox.ac.uk/software.html?id=tracer). Trees generated prior to stabilization of ML scores were discarded (burn-in of $10 \%)$.

The S-H test was also used to compare tree topologies (NJ, ML and Bayesian methods) based on concatenated data.

DNA-DNA hybridization. DNA was extracted and purified according to Brenner et al. (1982), except for X. axonopodis $\mathrm{LMG} 982^{\mathrm{T}}$, for which DNA was extracted using the CTAB method (Ausubel et al., 1991). Native DNAs of $X$. axonopodis LMG $982^{\mathrm{T}}$ and of pathotype strains of pv. mangiferaeindicae (CFBP 1716) and pv. citri (CFBP 2525) were labelled in vitro with tritium-labelled nucleotides by random priming using the Megaprime DNA labelling system 1604 (GE Healthcare). The S1 nuclease/trichloroacetic acid (TCA) method was used for DDH experiments as described by Grimont et al. (1980), except that hybridizations were performed for $24 \mathrm{~h}$ instead of $16 \mathrm{~h}$. The reassociation temperatures used were 70 and $75{ }^{\circ} \mathrm{C}$. DDH experiments were performed twice.

Thermal stability of DNA reassociation. For strains sharing reassociation values between 50 and $70 \%$, the thermal stability of DNA was determined (Crosa et al., 1973; Grimont, 1988). This technique determines by interpolation the DNA $T_{\mathrm{m}}$ (thermal denaturation midpoint), which is the temperature at which half of the reassociation of the DNA is obtained. The $T_{\mathrm{m}}$ value depends on both DNA base composition and ionic strength: the $T_{\mathrm{m}}$ of a DNA can be lowered by decreasing the sodium molarity (Grimont, 1988). This property was used to reduce artificially the theoretical $T_{\mathrm{m}}$ of our strains $\left(102{ }^{\circ} \mathrm{C}\right.$ after calculations). After $24 \mathrm{~h}$ hybridizations at 75 or $70{ }^{\circ} \mathrm{C}$ in $0.42 \mathrm{M} \mathrm{NaCl}$, the hybridization mixture was diluted 2-fold, in order to have a sodium molarity of $0.2 \mathrm{M}$, which decreased the $T_{\mathrm{m}}$ by $5{ }^{\circ} \mathrm{C}$. Then, as described by Grimont (1988), the temperature was raised in $5{ }^{\circ} \mathrm{C}$ increments (from 80 to $100{ }^{\circ} \mathrm{C}$ ). At each step, a sample was taken, and nuclease S1 buffer was added that contained $0.67 \mathrm{M}$ of $\mathrm{NaCl}$ in order to obtain the $0.42 \mathrm{M}$ of sodium required for nuclease $\mathrm{S} 1$ digestion. Further steps of $T_{\mathrm{m}}$ determination were similar to the original method (Crosa et al., 1973; Grimont, 1988). $\Delta T_{\mathrm{m}}$ or divergence corresponds to the difference between the $T_{\mathrm{m}}$ of a homologous reaction and the $T_{\mathrm{m}}$ of a heterologous reaction (Grimont, 1988).

\section{RESULTS}

\section{AFLP analysis}

Cluster analysis, based on 1308 AFLP fragments, placed most Xanthomonas genomospecies in distinct lineages, supported by high bootstraps values $(>80 \%)$ (Fig. 1). Strains identified as pathovars of $X$. axonopodis were distributed in six clusters, corresponding to subgroups 9.1 to 9.6 sensu Rademaker et al. (2005). Each subgroup was supported by bootstrap values above $80 \%$. Strains associated with members of the Anacardiaceae (indicated in bold in Fig. 1) were heterogeneous and grouped in three of the six subgroups in X. axonopodis. Among strains pathogenic to members of the Anacardiaceae, pathovar mangiferaeindicae from mango (CFBP 1716, 2916, 2917, 2927, 2932, 2933 and 2935, A11-1, JF30-1, JK147-1, JN570 and JV1121) and Brazilian pepper (CFBP 2938 and 2940 and JP758) was most closely related to subgroup 9.5 (synonym X. citri) (Table 1), with EGD $\geqslant 0.042$ nucleotide substitutions per site (nsps), and constituted a novel clade within this subgroup (bootstrap $100 \%$ ) (Fig. 1). Pathovar anacardii from cashew (LA98 and LA100) and mango (CFBP 2913 and 2914) grouped with strains identified as subgroup 9.6 (synonym $X$. fuscans) (Table 1), with EGD $\geqslant 0.025$ nsps, and pathovar spondiae from ambarella was most closely related to $X$. axonopodis subgroup 9.4 (with EGD $\geqslant 0.048$ nsps).

Comparisons between the type strain of $X$. axonopodis (LMG $982^{\mathrm{T}}$ ) and the pathotype strains of pathovars anacardii (CFBP 2913), mangiferaeindicae (CFBP 1716) and spondiae (CFBP 2547) suggested that strains pathogenic to members of the Anacardiaceae should not be classified as $X$. axonopodis (EGD $\geqslant 0.118 \mathrm{nsps}$ ) (Table 1 ). The type strains of $X$. citri and $X$. fuscans diverged by 0.080 nsps.

Subgroup 9.5 contained strains of pathovars bauhiniae, cajani, citri, clitoriae, desmodiilaxiflori, glycines, malvacearum and mangiferaeindicae. Pathovar mangiferaeindicae 


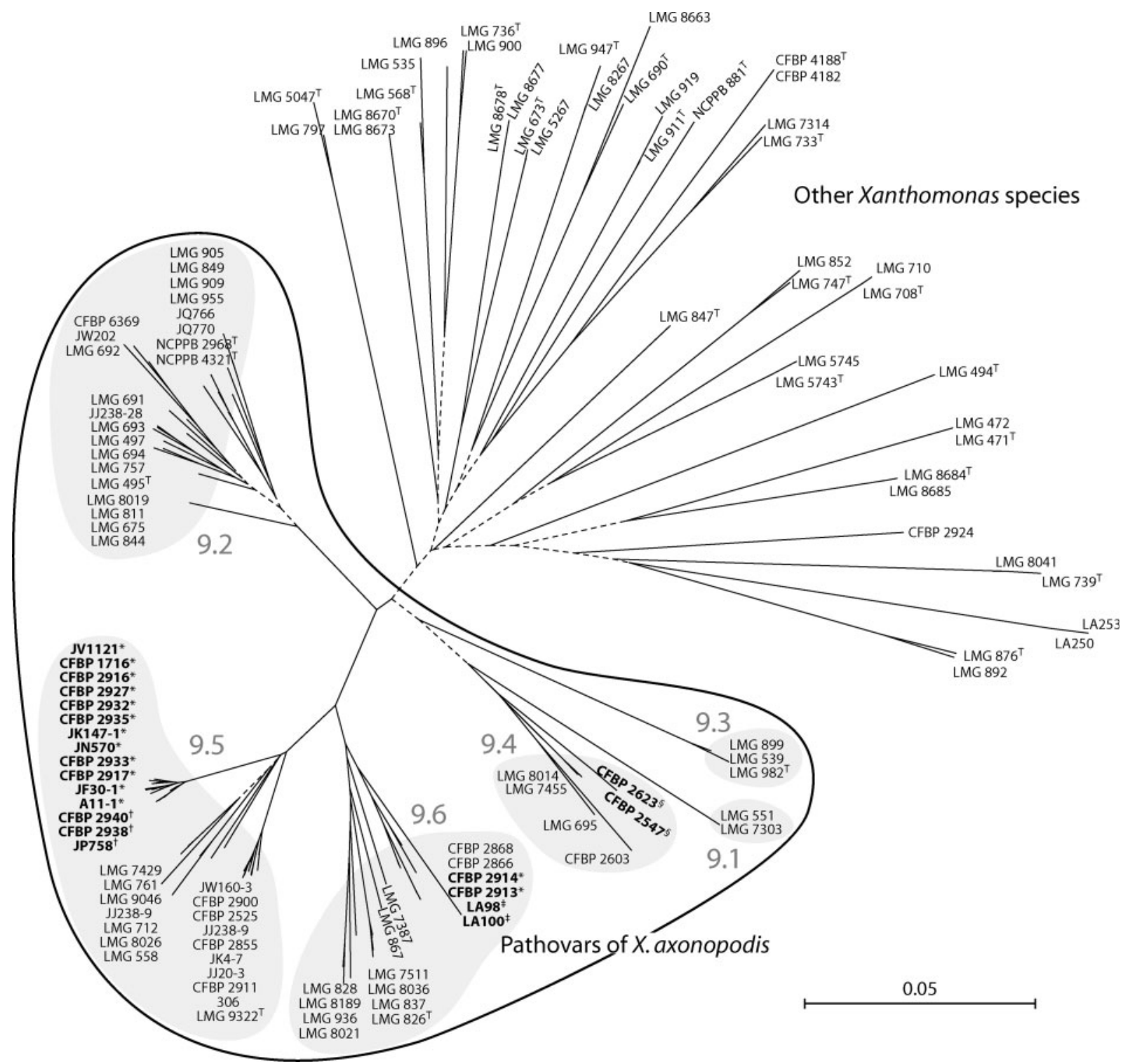

Fig. 1. NJ tree derived from EGDs (Mougel et al., 2002; Portier et al., 2006) showing the relationships between Xanthomonas genomospecies and xanthomonads pathogenic to members of the Anacardiaceae based on 1308 AFLP markers. Branches with bootstrap values lower than $80 \%$ are represented by dotted lines. Isolation sources of strains pathogenic to members of the Anacardiaceae (in bold) are indicated by * (mango), † (Brazilian pepper), $\ddagger$ (cashew) and $\S$ (ambarella). Bar, 0.05 substitutions per site.

was most closely related to pathovar citri. Subgroup 9.6 contained strains of pathovars anacardii, aurantifolii, cajani, dieffenbachiae and phaseoli var. fuscans. Strains of pathovar anacardii were most closely related to $X$. axonopodis pv. aurantifolii. Strains of pathovar spondiae were most closely related to the pathotype strain of $X$. axonopodis pv. dieffenbachiae (subgroup 9.4).

\section{Multilocus sequence analysis}

The nucleotide identity of the three gene portions ranged from $96.53 \% \quad(g y r B)$ to $96.94 \% \quad($ atpD) (Table 2).
Nucleotide transitions exceeded transversions, with ratios ranging from $1.47(\mathrm{SD}=1.50)(\operatorname{atpD})$ to $3.51(\mathrm{sD}=2.77)$ $($ gyrB $)$. The $K_{\mathrm{a}} / K_{\mathrm{s}}$ ratios of the three genes $(\ll 1)$ indicated that these genes are under purifying selection (i.e. a type of selection in which genetic diversity decreases as the population stabilizes on a particular trait value). No recombination event was detected within $X$. citri.

The S-H test performed on ML trees from each gene showed that the topologies of the $a t p D, d n a K$ and $g y r B$ ML trees fell within the same confidence interval as that of the concatenated dataset (1000 bootstraps). ML trees based on 
Table 2. Sequence variation for three housekeeping genes within Xanthomonas strains used in this study

Transition/transversion ratios (Ts/Tv) were determined using Kimura's two-parameter method (Kimura, 1980). Synonymous $\left(K_{\mathrm{s}}\right)$ and non-synonymous $\left(K_{\mathrm{a}}\right)$ substitution rates were determined using the method of Nei \& Gojobori (1986). Values in parentheses are standard deviations. The values of Tajima's D are not significant $(P>0.10)$.

\begin{tabular}{|lccc|}
\hline Gene & $\boldsymbol{a t p D}$ & $\boldsymbol{g y r} \boldsymbol{B}$ & $\boldsymbol{d n a K}$ \\
\hline Length (bp) & 747 & 773 & 762 \\
Sequence identity (\%) & & & \\
$\quad$ Nucleotide & 96.96 & 96.57 & 96.81 \\
$\quad$ Amino acid & 99.26 & 99.55 & 99.67 \\
Ts/Tv & $1.4667(1.5185)$ & $3.5412(2.7858)$ & $3.1145(1.8021)$ \\
$K_{\mathrm{a}}$ & $0.0084(0.0072)$ & $0.0020(0.0030)$ & $0.0015(0.0014)$ \\
$K_{\mathrm{s}}$ & $0.1235(0.0740)$ & $0.1666(0.1053)$ & $0.1509(0.0806)$ \\
$K_{\mathrm{a}} / K_{\mathrm{s}}$ & $0.0678(0.0478)$ & $0.0119(0.0118)$ & $0.0102(0.0239)$ \\
Tajima's D & -0.529 & -0.618 & -0.124 \\
\hline
\end{tabular}

single gene sequences ( $a t p D, d n a K$ and $g y r B$ ) showed that xanthomonads originating from members of the Anacardiaceae [i.e. X. campestris pv. mangiferaeindicae sensu Dye et al. (1980)] are distributed into three different lineages (not shown). Each tree showed that strains of pathovars mangiferaeindicae and anacardii grouped with strains of subgroup 9.5 and 9.6, respectively, regardless of which gene was analysed. The pathovar composition of subgroups 9.5 and 9.6 was identical to that described for AFLP analysis. Subgroups 9.5 and 9.6 were always closely related, an association supported by high bootstrap values $(\geqslant 80 \%)$ for atpD and gyrB (Supplementary Figs S1-S3). Strains identified as pv. spondiae grouped with subgroup 9.1 ( gyrB) or subgroup 9.4 ( $a t p D$ and $d n a K$ ) (Supplementary Figs S1-S3).

When using concatenated sequences, the general time reversible (GTR) model with gamma $(\Gamma)$ variations and a proportion of invariable sites (I) was the most suitable model, based on the Akaike information criterion. This model was used for building NJ, ML and Bayesian trees. The three methods gave congruent results in tree topologies, supported by high bootstrap and probability values. Based on the $\mathrm{S}-\mathrm{H}$ test, the best tree likelihood was obtained with the ML method. All strains of X. axonopodis sensu Vauterin et al. (1995), together with X. euvesicatoria and X. perforans (Jones et al., 2004, 2006), clustered in a very robust but heterogeneous group. Consistent with data from single gene sequences, strains of pathovars mangiferaeindicae and anacardii grouped with strains belonging to subgroups 9.5 and 9.6, respectively (Fig. 2).

Distance matrices calculated with the model GTR $+\Gamma+\mathrm{I}$, based on concatenated sequences, allowed us to assess relationships between strains. Distances within subgroup 9.5 were very short ( $\leqslant 0.004$ nsps). Subgroups 9.5 and 9.6 were closely related to each other, with a mean sequence distance of $0.022 \mathrm{nsps}(\mathrm{SD}=0.002)$. The distance between the type strains of $X$. citri and X. fuscans was $0.021 \mathrm{nsps}$. The distance between the pathotype strains of pathovars mangiferaeindicae and anacardii, both pathogenic to members of the Anacardiaceae, was 0.020 nsps. $X$. axonopodis subgroup 9.5 and 9.6 constituted robust clades, as did the clade composed of the two subgroups (Fig. 2). Mean distance values between subgroup 9.5 and other $X$. axonopodis subgroups (9.1-9.4) ranged from 0.036 to 0.047 nsps. Strains of pv. spondiae were equidistantly related to subgroups 9.1 (0.020 nsps) and 9.4 (0.019 to $0.023 \mathrm{nsps})$. The latter two subgroups were closely related, with a mean sequence distance of $0.023 \mathrm{nsps}(\mathrm{SD}=0.002)$.

Distances between the pathotype strains of pathovars mangiferaeindicae, anacardii and spondiae (pathogenic to members of the Anacardiaceae) and the type strain of $X$. axonopodis sensu Vauterin et al. (1995) were 0.041, 0.048 and $0.045 \mathrm{nsps}$, respectively. These strains from members of the Anacardiaceae were also distantly related to the type strain of the recently described Xanthomonas species $X$. perforans, $X$. euvesicatoria and X. gardneri, with distances ranging from 0.033 to 0.078 nsps.

\section{DDH and $\Delta T_{\mathrm{m}}$ values}

The level of DNA reassociation between pv. mangiferaeindicae pathotype strain CFBP 1716 (labelled) and the type strains of most selected species of the genus Xanthomonas was below $40 \% . \Delta T_{\mathrm{m}}$ values obtained between CFBP 1716 and the type strains of Xanthomonas oryzae, X. melonis and $X$. axonopodis were $>5.0{ }^{\circ} \mathrm{C}$ (Table 3). Other $\Delta T_{\mathrm{m}}$ results (Table 3 ) indicated that the pathotype strains of $X$. axonopodis pathovars citri (CFBP 2525), anacardii (CFPB 2913) and mangiferaeindicae (CFBP 1716) should not be classified as members of $X$. axonopodis and should be classified within a single species.

\section{Sequencing of the 165 rRNA gene}

A fragment of 1545 bp was amplified from strains CFBP 1716 (pv. mangiferaeindicae), CFBP 2547 (pv. spondiae) 


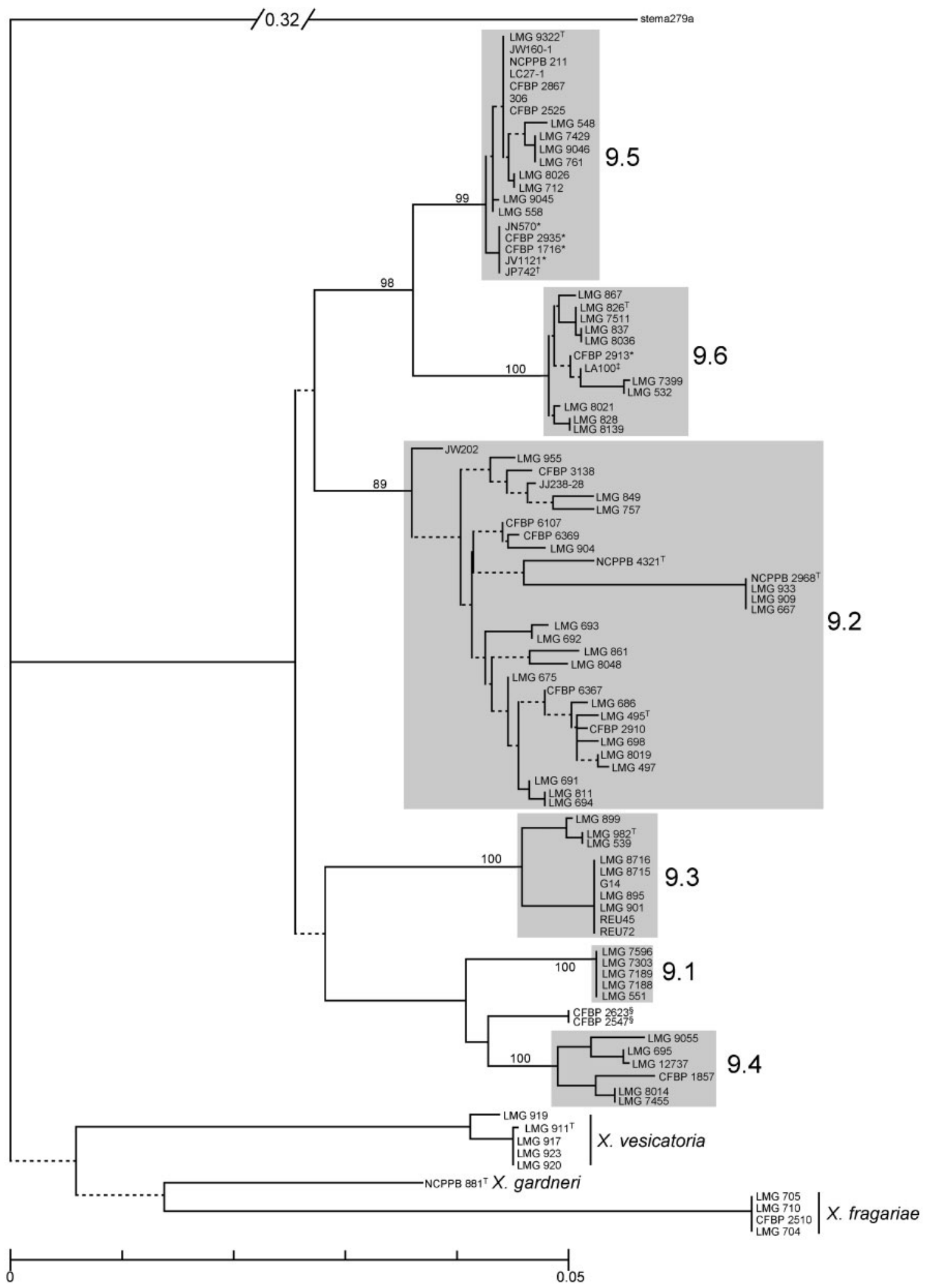

Fig. 2. $M L$ tree derived from the GTR $+\Gamma+I$ model, based on concatenated partial atp $D$, dnaK and gyr $B$ sequences, showing the relationships between $X$. axonopodis subgroups (Rademaker et al., 2000, 2005) and xanthomonads pathogenic to members of the Anacardiaceae. Branches with bootstrap values lower than $80 \%$ are represented by dotted lines. Isolation sources of strains pathogenic to members of the Anacardiaceae (in bold) are indicated by * (mango), † (Brazilian pepper), $\ddagger$ (cashew) and § (ambarella). 
Table 3. Levels of DNA-DNA reassociation between the pathotype strain of pathovar mangiferaeindicae and selected Xanthomonas type strains and pathotype strains

Values in italics indicate that the considered bacteria should be classified within a single species, according to the defined threshold for bacterial species (Wayne et al., 1987). Values in bold indicate that the considered bacteria should be classified within separate species. PT, Pathotype strain; $\mathrm{RBR}$, relative binding ratio; ND, not determined.

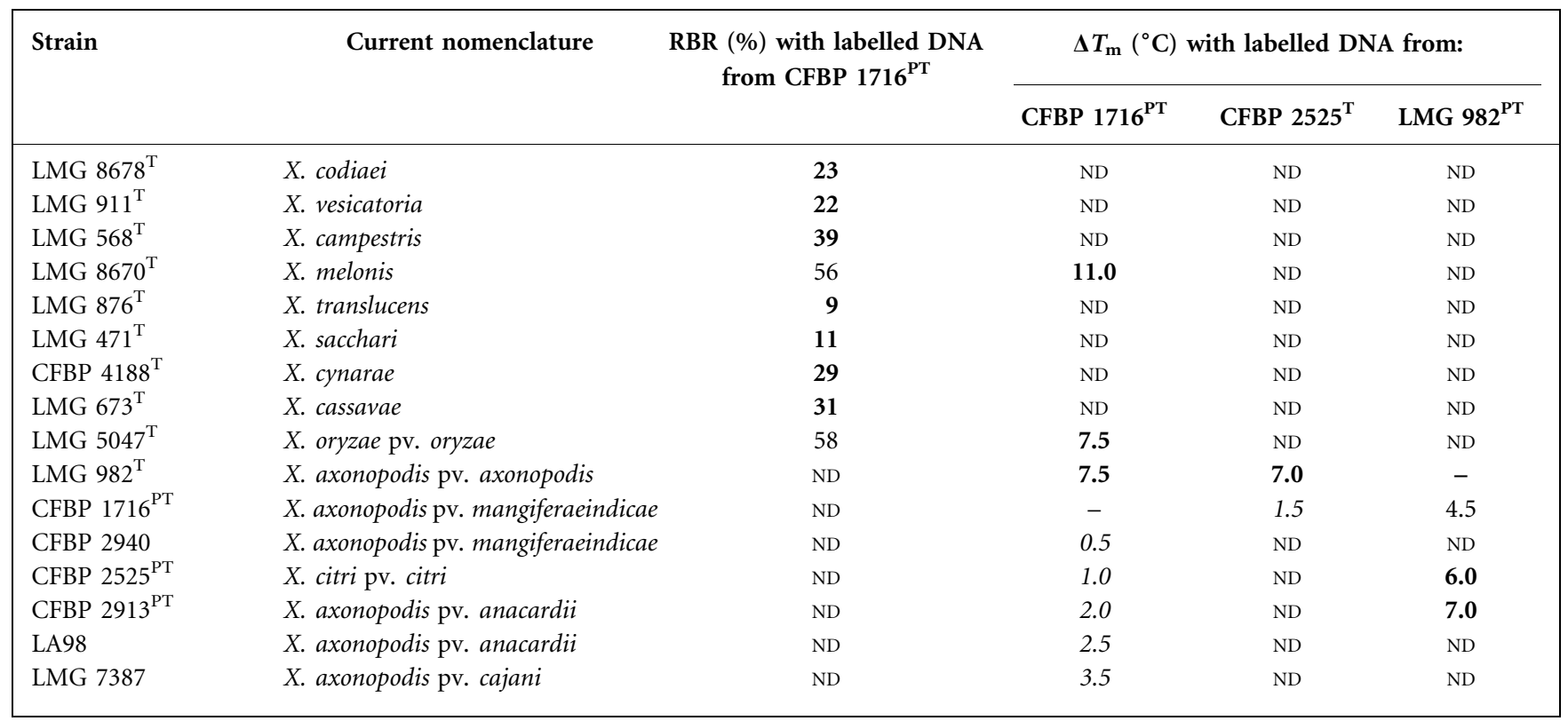

and CFBP 2913 (pv. anacardii). Their respective DNA sequences shared more than $99 \%$ similarity with members of the $X$. campestris rRNA gene core and were more distantly related to the Xanthomonas sacchari and Xanthomonas translucens core. The sequence obtained for CFBP 1716 differed from those of strains CFBP 2913 and CFBP 2547 by six and five nucleotides, respectively. It was most closely related to those of $X$. axonopodis $\mathrm{pv}$. citri strain 306 (GenBank accession no. NC_003919) and Xanthomonas vasicola LMG $736^{\mathrm{T}}$ (Y10755), with a sequence difference of one nucleotide. In contrast, the sequences of strains CFBP 2913 and CFBP 2547 were most closely related to those of X. perforans XV938 ${ }^{\mathrm{T}}$ (GenBank accession no. AF123091) or X. euvesicatoria XV153 (AF123089) (the latter two sequences were $100 \%$ identical), from which they differed by three and four nucleotides, respectively.

\section{DISCUSSION}

Our study aimed to determine the taxonomic position of $X$. campestris pv. mangiferaeindicae sensu Dye et al. (1980). We used AFLP and MLSA on a broad collection of strains to define a relevant subset of strains to be used in DDH experiments in order to refine relationships of these strains in relation to Xanthomonas species and the infraspecific genetic clusters of $X$. axonopodis reported by Rademaker et al. (2000) and Roumagnac et al. (2004). Variations in pathogenicity within $X$. campestris pv. mangiferaeindicae supported its partition into three pathovars, namely pv. mangiferaeindicae, pv. anacardii and pv. spondiae (Ah-You et al., 2007). The AFLP and MLSA data supported placement of these three pathovars separately in three of the six subgroups defined within $X$. axonopodis (Rademaker et al., 2005). However, divergence between the type strain of $X$. axonopodis sensu Vauterin et al. (1995) and strains of pathovars anacardii, mangiferaeindicae and spondiae suggested that their assignment to $X$. axonopodis would be incorrect. Data from both techniques indicated that pathovars mangiferaeindicae and anacardii were most closely related to $X$. citri (syn. $X$. axonopodis subgroup 9.5) and $X$. fuscans (syn. $X$. axonopodis subgroup 9.6), respectively. The strains of pathovar spondiae were most closely related to subgroup 9.4 of $X$. axonopodis by AFLP, but equidistantly related to subgroups 9.1 and 9.4 by MLSA. This difference complicates the classification of these strains and illustrates the relatively close relationships within group 9 (Vauterin et al., 1995). Additional analysis, including an extended MLSA scheme, may clarify the classification of the strains of pathovar spondiae. With the exception of this example, pathovar assignment to $X$. axonopodis subgroups was identical by AFLP and MLSA, and our data support conclusions based on previously published rep-PCR data (Rademaker et al., 2005).

Sequence-based analyses of the structure of the genus Xanthomonas have been published, but they have targeted either the ribosomal operon (Goncalves \& Rosato, 2002; Hauben et al., 1997; Schaad et al., 2005) or a single housekeeping gene (Cubero \& Graham, 2004). To our knowledge, our study is the first step towards an MLSA 
scheme for the genus Xanthomonas. The three studied housekeeping genes $(d n a K, g y r B$ and $a t p D)$ were under purifying selection, and no recombination event concerned members of $X$. citri. All three single-sequence analyses yielded ML tree topologies non-significantly different from that derived from the concatenated dataset based on the $\mathrm{S}-\mathrm{H}$ test, indicating that the observed groups were congruent. When using concatenated gene datasets, NJ, $\mathrm{ML}$ and Bayesian trees were of similar structures, with ML having the highest likelihood ( $\mathrm{S}-\mathrm{H}$ test). MLSA data (Fig. 2) were consistent with AFLP results (Fig. 1), and both techniques appeared to be powerful tools for studying the taxonomy of Xanthomonas.

We performed DDH, using the nuclease S1/TCA method under internationally recommended stringency conditions $\left(T_{\mathrm{m}}-25^{\circ} \mathrm{C}\right)$ (Johnson, 1984), and strengthened our results, when appropriate, by evaluating the thermal stability of DNA reassociation $\left(\Delta T_{\mathrm{m}}\right)$, which is recommended for species delineation, especially when $\mathrm{DDH}$ values are in the range 50-75\% (Crosa et al., 1973; Grimont et al., 1980; Grimont, 1988). Based on AFLP data, 11 genomospecies were selected for DDH experiments $(X$. axonopodis, $X$. citri, $X$. codiaei, $X$. vesicatoria, $X$. campestris, $X$. melonis, $X$. translucens, X. sacchari, X. cynarae, $X$. cassavae and $X$. oryzae). When the pathotype strain of pathovar mangiferaeindicae was labelled, most species had $\mathrm{DDH}$ values lower than $40 \% . \Delta T_{\mathrm{m}}$ values with the three species that were most closely related to pathovar mangiferaeindicae ( $X$. oryzae, $X$. melonis and $X$. axonopodis) were greater than the widely accepted threshold of $5{ }^{\circ} \mathrm{C}$ for species delineation (Wayne et al., 1987). The relationships between the pathotype strains of pathovars mangiferaeindicae and citri and the type strain of $X$. axonopodis sensu Vauterin et al. (1995) were further examined. Whatever the labelled strain, $\Delta T_{\mathrm{m}}$ values between the type strain of $X$. axonopodis and these two members of subgroup 9.5 were greater than $5{ }^{\circ} \mathrm{C}$; the only exception was hybridization of $X$. axonopodis (labelled) to pv. mangiferaeindicae, which indicated a $\Delta T_{\mathrm{m}}$ of $4.5^{\circ} \mathrm{C} . \Delta T_{\mathrm{m}}$ values in the range $6-7{ }^{\circ} \mathrm{C}$ (obtained between $X$. citri and $X$. axonopodis) corresponded to EGD values (derived from AFLP) of about 0.12 and to genetic distances (derived from MLSA) of about 0.04 nsps. Our data fully support the elevation of $X$. axonopodis pv. citri to species rank, as $X$. citri (ex Hasse 1915) Gabriel et al. 1989 emend Schaad et al. 2006.

Reciprocal DDH and thermal stability of DNA reassociation showed a close relationship between pathovars mangiferaeindicae and citri, indicating that these pathovars should both be part of the $X$. citri genomospecies. The distances between these strains by AFLP and MLSA were fully consistent with $\Delta T_{\mathrm{m}}$ results (Table 1). Based on AFLP and MLSA data, all pathovars of $X$. axonopodis subgroup 9.5 formed a homogeneous group, with AFLP distances ranging from 0.042 to $0.065 \mathrm{nsps}$ and MLSA distances lower than 0.005 nsps. We therefore propose that all pathovars presently identified as $X$. axonopodis subgroup
9.5 sensu Rademaker et al. (2005) should be reclassified as pathovars of $X$. citri.

Values of $\Delta T_{\mathrm{m}}$ between the pathotype strain of pathovar mangiferaeindicae (subgroup 9.5) and strains CFBP 2913 and LA98 of pathovar anacardii (subgroup 9.6) were 2.0 and $2.5^{\circ} \mathrm{C}$, respectively. These values are below the $5{ }^{\circ} \mathrm{C}$ threshold for species delineation (Wayne et al., 1987), suggesting that they are members of the same species. These $\Delta T_{\mathrm{m}}$ values corresponded to distances of 0.062 and $0.073 \mathrm{nsps}$ (AFLP) and 0.020 and $0.021 \mathrm{nsps}$ (MLSA), respectively.

Our AFLP and MLSA results confirmed the genetic relatedness of $X$. citri and $X$. fuscans ( $X$. axonopodis subgroups 9.5 and 9.6, respectively), already outlined using different AFLP conditions (Rademaker et al., 2000; Roumagnac et al., 2004) and rep-PCR (Rademaker et al., 2005). Recently, Schaad et al. (2005) proposed the elevation of two pathovars of $X$. axonopodis subgroup 9.6 to species level as $X$. fuscans. Distances derived from AFLP and MLSA between the type strains of $X$. citri and $X$. fuscans were slightly greater but similar to distances between the pathotype strains of pathovars anacardii and mangiferaeindicae (Table 4). $\Delta T_{\mathrm{m}}$ values for the latter strains were only $2.0-2.5^{\circ} \mathrm{C}$. Globally, our data do not support the classification of $X$. axonopodis subgroup 9.6 as $X$. fuscans. We therefore propose that this name be considered to be a later synonym of $X$. citri, for which an emended description is provided below.

\section{Emended description of Xanthomonas citri (ex Hasse 1915) Gabriel et al. 1989}

Xanthomonas citri (ci'tri. L. gen. n. citri of citrus).

Later heterotypic synonym: Xanthomonas fuscans Schaad et al. 2007.

The description of the species $X$. citri is encompassed by the description of the genus Xanthomonas Dowson 1939 emend. Vauterin et al. (1995) and by the description provided by Gabriel et al. (1989). X. citri can be differentiated from all other Xanthomonas species by DDH assays (Schaad et al., 2005; this study), rep-PCR profiles (Rademaker et al., 2000, 2005), AFLP (Rademaker et al., 2000; Roumagnac et al., 2004; Schaad et al., 2005; this study) and MLSA (this study). X. citri is composed of strains previously identified as $X$. axonopodis clusters 9.5 and 9.6 (Rademaker et al., 2000, 2005). X. citri comprises several pathovars, namely $X$. citri pv. anacardii, $X$. citri pv. aurantifolii (citri B, C and D groups), X. citri pv. bauhiniae, $X$. citri pv. cajani, X. citri pv. citri (citri A group), X. citri pv. clitoriae, $X$. citri pv. desmodiilaxiflori, $X$. citri pv. dieffenbachiae (strains not pathogenic to anthurium), X. citri pv. glycines, $X$. citri pv. malvacearum, X. citri pv. mangiferaeindicae, $X$. citri pv. phaseoli var. fuscans, X. citri pv. rhynchosiae, $X$. citri pv. sesbaniae, $X$. citri pv. vignaeradiatae and $X$. citri pv. vignicola. The DNA G $+\mathrm{C}$ content is 64.6$67.5 \mathrm{~mol} \%$ (Swings \& Civerolo, 1993). 
Table 4. Genetic relatedness between members of $X$. axonopodis groups 9.5 (syn. X. citri) and 9.6 (syn. X. fuscans)

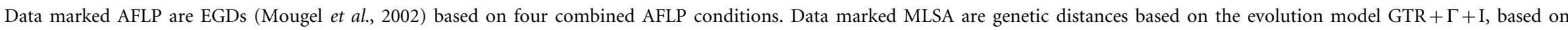

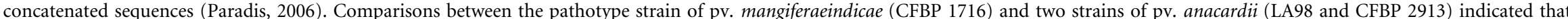
EGD (derived from AFLP) values of 0.062 and 0.073 nsps corresponded to distances (MLSA) of 0.021 and 0.020 nsps and to $\Delta T_{\mathrm{m}}$ values of 2.0 and $2.5{ }^{\circ} \mathrm{C}$, respectively. PT, Pathotype strain.

\begin{tabular}{|c|c|c|c|c|c|c|c|c|c|c|c|c|c|}
\hline \multirow[t]{3}{*}{ Strain } & \multirow[t]{3}{*}{ Pathovar } & \multicolumn{4}{|c|}{ pv. anacardii } & \multicolumn{8}{|c|}{ pv. phaseoli var. fuscans } \\
\hline & & \multicolumn{2}{|c|}{ CFBP $2913^{\mathrm{PT}}$} & \multicolumn{2}{|c|}{ LA100 } & \multicolumn{2}{|c|}{ LMG $826^{\mathrm{T}}$} & \multicolumn{2}{|c|}{ LMG 837} & \multicolumn{2}{|c|}{ LMG 7511} & \multicolumn{2}{|c|}{ LMG 8036} \\
\hline & & AFLP & MLSA & AFLP & MLSA & AFLP & MLSA & AFLP & MLSA & AFLP & MLSA & AFLP & MLSA \\
\hline LMG $558^{\mathrm{PT}}$ & cajani & 0.0673 & 0.0197 & 0.0617 & 0.0210 & 0.0719 & 0.0202 & 0.0737 & 0.0206 & 0.0789 & 0.0202 & 0.0761 & 0.0206 \\
\hline LMG $9322^{\mathrm{T}}$ & citri & 0.0710 & 0.0210 & 0.0667 & 0.0223 & 0.0798 & 0.0214 & 0.0787 & 0.0219 & 0.0847 & 0.0214 & 0.0831 & 0.0219 \\
\hline CFBP $2525^{\mathrm{PT}}$ & citri & 0.0724 & 0.0210 & 0.0662 & 0.0223 & 0.0818 & 0.0214 & 0.0816 & 0.0219 & 0.0876 & 0.0214 & 0.0862 & 0.0219 \\
\hline $306^{*}$ & citri & 0.0715 & 0.0210 & 0.0654 & 0.0223 & 0.0788 & 0.0214 & 0.0787 & 0.0219 & 0.0846 & 0.0214 & 0.0832 & 0.0219 \\
\hline LMG $9045^{\mathrm{PT}}$ & clitoriae & 0.0761 & 0.0202 & 0.0718 & 0.0214 & 0.0784 & 0.0206 & 0.0783 & 0.0211 & 0.0855 & 0.0206 & 0.0826 & 0.0211 \\
\hline LMG $9046^{\mathrm{PT}}$ & desmodiilaxiflori & 0.0805 & 0.0210 & 0.0777 & 0.0223 & 0.0795 & 0.0228 & 0.0811 & 0.0232 & 0.0852 & 0.0227 & 0.0821 & 0.0232 \\
\hline LMG $712^{\mathrm{PT}}$ & glycines & 0.0818 & 0.0208 & 0.0791 & 0.0221 & 0.0809 & 0.0213 & 0.0825 & 0.0217 & 0.0883 & 0.0213 & 0.0889 & 0.0217 \\
\hline LMG 8026 & glycines & 0.0880 & 0.0208 & 0.0896 & 0.0221 & 0.0852 & 0.0213 & 0.0887 & 0.0217 & 0.0913 & 0.0213 & 0.0919 & 0.0217 \\
\hline LMG $761^{\mathrm{PT}}$ & malvacearum & 0.0804 & 0.0210 & 0.0736 & 0.0223 & 0.0754 & 0.0228 & 0.0792 & 0.0232 & 0.0817 & 0.0228 & 0.0822 & 0.0232 \\
\hline LMG 7429 & malvacearum & 0.0821 & 0.0210 & 0.0774 & 0.0223 & 0.0793 & 0.0228 & 0.0809 & 0.0232 & 0.0834 & 0.0228 & 0.0838 & 0.0232 \\
\hline CFBP $1716^{\mathrm{PT}}$ & mangiferaeindicae & 0.0730 & 0.0197 & 0.0636 & 0.0210 & 0.0770 & 0.0202 & 0.0788 & 0.0206 & 0.0829 & 0.0202 & 0.0816 & 0.0206 \\
\hline JN570 & mangiferaeindicae & 0.0748 & 0.0197 & 0.0660 & 0.0210 & 0.0787 & 0.0202 & 0.0803 & 0.0206 & 0.0842 & 0.0202 & 0.0829 & 0.0206 \\
\hline
\end{tabular}

${ }^{*}$ Complete genome sequence reported by Da Silva et al. (2002). 
The type strain is strain $3213^{\mathrm{T}}=$ ATCC $49118^{\mathrm{T}}=\mathrm{ICMP}$ $15804^{\mathrm{T}}=$ ICPB $10518^{\mathrm{T}}=$ LMG $9322^{\mathrm{T}}$.

\section{ACKNOWLEDGEMENTS}

We thank J. M. Young for manuscript review before submission and English language editing and C. Boyer, K. Vital, V. Ledoux and F. Mondon for technical assistance. The European Union (FEOGA), Conseil Régional de La Réunion and CIRAD provided financial support.

\section{REFERENCES}

Aabenhus, R., On, S. L. W., Siemer, B. L., Permin, H. \& Andersen, L. P. (2005). Delineation of Campylobacter concisus genomospecies by amplified fragment length polymorphism analysis and correlation of results with clinical data. J Clin Microbiol 43, 5091-5096.

Ah-You, N., Gagnevin, L., Chiroleu, F., Jouen, E., Neto, J. R. \& Pruvost, O. (2007). Pathological variations within Xanthomonas campestris pv. mangiferaeindicae support its separation into three distinct pathovars that can be distinguished by amplified fragment length polymorphism. Phytopathology 97, 1568-1577.

Ausubel, F. M., Brent, R., Kingston, R. E., Moore, D. D., Seidman, J. G., Smith, J. A. \& Struhl, K. (1991). Current Protocols in Molecular Biology. New York: Wiley.

Boudon, S., Manceau, C. \& Notteghem, J. L. (2005). Structure and origin of Xanthomonas arboricola pv. pruni populations causing bacterial spot of stone fruit trees in Western Europe. Phytopathology 95, 1081-1088.

Brenner, D. J., McWhorter, A. C., Leete-Knutson, J. K. \& Steigerwalt, A. G. (1982). Escherichia vulneris: a new species of Enterobacteriaceae associated with human wounds. J Clin Microbiol 15, 1133-1140.

Chelo, I. M., Zé-Zé, L. \& Tenreiro, R. (2007). Congruence of evolutionary relationships inside the Leuconostoc-OenococcusWeissella clade assessed by phylogenetic analysis of the 16S rRNA gene, dnaA, gyrB, rpoC and dnaK. Int J Syst Evol Microbiol 57, 276286.

Crosa, J. H., Brenner, D. J. \& Falkow, S. (1973). Use of a single-strand specific nuclease for analysis of bacterial and plasmid deoxyribonucleic acid homo- and heteroduplexes. J Bacteriol 115, 904-911.

Cubero, J. \& Graham, J. H. (2004). The leucine-responsive regulatory protein $(\operatorname{lrp})$ gene for characterization of the relationship among Xanthomonas species. Int J Syst Evol Microbiol 54, 429-437.

Da Silva, A. C., Ferro, J. A., Reinach, F. C., Farah, C. S., Furlan, L. R., Quaggio, R. B., Monteiro-Vitorello, C. B., Van Sluys, M. A., Almeida, N. F. \& other authors (2002). Comparison of the genomes of two Xanthomonas pathogens with differing host specificities. Nature 417, 459-463.

Doidge, E. M. (1915). A bacterial disease of the mango. Bacillus mangiferae n. sp. Ann Appl Biol 2, 1-44.

Dye, D. W., Bradbury, J. F., Goto, M., Hayward, A. C., Lelliott, R. A. \& Schroth, M. N. (1980). International standards for naming pathovars of phytopathogenic bacteria and a list of pathovar names and pathotype strains. Rev Plant Pathol 59, 153-168.

Gabriel, D. W., Kingsley, M. T., Hunter, J. E. \& Gottwald, T. (1989). Reinstatement of Xanthomonas citri (ex Hasse) and X. phaseoli (ex Smith) to species and reclassification of all $X$. campestris pv. citri strains. Int J Syst Bacteriol 39, 14-22.

Gagnevin, L. \& Pruvost, O. (2001). Epidemiology and control of mango bacterial black spot. Plant Dis 85, 928-935.
Gascuel, O. (1997). Concerning the NJ algorithm and its unweighted version UNJ. In Mathematical Hierarchies and Biology, pp. 149-171. Edited by B. Mirkin, F. R. McMorris, F. Roberts \& A. Rzhetsky. Providence, RI: American Mathematical Society.

Gevers, D., Cohan, F. M., Lawrence, J. G., Spratt, B. G., Coenye, T., Feil, E. J., Stackebrandt, E., Van de Peer, Y., Vandamme, P. \& other authors (2005). Re-evaluating prokaryotic species. Nat Rev Microbiol 3, 733-739.

Goncalves, E. R. \& Rosato, Y. B. (2002). Phylogenetic analysis of Xanthomonas species based upon 16S-23S rDNA intergenic spacer sequences. Int J Syst Evol Microbiol 52, 355-361.

Grimont, P. A. D. (1988). Use of DNA reassociation in bacterial classification. Can J Microbiol 34, 541-546.

Grimont, P. A. D., Popoff, M. Y., Grimont, F., Coynault, C. \& Lemelin, M. (1980). Reproducibility and correlation study of three deoxyribonucleic acid hybridization procedures. Curr Microbiol 4, 325-330.

Guindon, S. \& Gascuel, O. (2003). A simple, fast, and accurate algorithm to estimate large phylogenies by maximum likelihood. Syst Biol 52, 696-704.

Hanage, W. P., Fraser, C. \& Spratt, B. G. (2005a). Fuzzy species among recombinogenic bacteria. $B M C$ Biol 3, 6.

Hanage, W. P., Kaijalainen, T., Herva, E., Saukkoriipi, A., Syrjänen, R. \& Spratt, B. G. (2005b). Using multilocus sequence data to define the pneumococcus. J Bacteriol 187, 6223-6230.

Hauben, L., Vauterin, L., Swings, J. \& Moore, E. R. B. (1997). Comparison of $16 \mathrm{~S}$ ribosomal DNA sequences of all Xanthomonas species. Int J Syst Bacteriol 47, 328-335.

Hong, Y., Garcia, M., Levisohn, S., Lysnyansky, I., Leiting, V., Savelkoul, P. H. M. \& Kleven, S. H. (2005). Evaluation of amplified fragment length polymorphism for differentiation of avian Mycoplasma species. J Clin Microbiol 43, 909-912.

Huelsenbeck, J. P. \& Ronquist, F. (2001). MRBAYES: Bayesian inference of phylogenetic trees. Bioinformatics 17, 754-755.

Huys, G., Rigouts, L., Chemlal, K., Portaels, F. \& Swings, J. (2000). Evaluation of amplified fragment length polymorphism analysis for inter- and intraspecific differentiation of Mycobacterium bovis, $M$. tuberculosis, and M. ulcerans. J Clin Microbiol 38, 3675-3680.

Janssen, P., Coopman, R., Huys, G., Swings, J., Bleeker, M., De Vos, P., Zabeau, M. \& Kersters, K. (1996). Evaluation of the DNA fingerprinting method AFLP as a new tool in bacterial taxonomy. Microbiology 142, 1881-1893.

Johnson, J. L. (1984). Nucleic acids in bacterial classification. In Bergey's Manual of Systematic Bacteriology, vol. 1, pp. 8-11. Edited by N. R. Krieg \& J. G. Holt. Baltimore: Williams \& Wilkins.

Jones, J. B., Lacy, G. H., Bouzar, H., Stall, R. E. \& Schaad, N. W. (2004). Reclassification of the xanthomonads associated with bacterial spot disease of tomato and pepper. Syst Appl Microbiol 27, 755-762.

Jones, J. B., Lacy, G. H., Bouzar, H., Stall, R. E. \& Schaad, N. W. (2006). Xanthomonas euvesicatoria sp. nov., Xanthomonas gardneri nom. rev., comb. nov. and Xanthomonas perforans sp. nov. In List of New Names and New Combinations Previously Effectively, but not Validly, Published, Validation List no. 109. Int J Syst Evol Microbiol 56, 925-927.

Kimura, M. (1980). A simple method for estimating evolutionary rates of base substitutions through comparative studies of nucleotide sequences. J Mol Evol 16, 111-120.

Kumar, S., Tamura, K. \& Nei, M. (2004). MEGA3: integrated software for molecular evolutionary genetics analysis and sequence alignment. Brief Bioinform 5, 150-163.

Lapage, S. P., Sneath, P. H. A., Lessel, E. F., Skerman, V. B. D., Seelinger, H. P. R. \& Clark, W. A. (editors) (1992). International Code 
of Nomenclature of Bacteria (1990 Revision) Bacteriological Code. Washington, DC: American Society for Microbiology.

Leal-Klevezas, D. S., Martinez-de-la-Vega, O., Ramirez-Barba, E. J., Osterman, B., Martinez-Soriano, J. P. \& Simpson, J. (2005). Genotyping of Ochrobactrum spp. by AFLP analysis. J Bacteriol 187, 2537-2539.

Martens, M., Delaere, M., Coopman, R., De Vos, P., Gillis, M. \& Willems, A. (2007). Multilocus sequence analysis of Ensifer and related taxa. Int J Syst Evol Microbiol 57, 489-503.

Martin, D. P., Williamson, C. \& Posada, D. (2005). RDP2: recombination detection and analysis from sequence alignments. Bioinformatics 21, 260-262.

Moore, E. R. B., Kruger, A. S., Hauben, L., Seal, S. E., De Baere, R., De Wachter, R., Timmis, K. N. \& Swings, J. (1997). 16S rRNA gene sequence analyses and inter- and intrageneric relationships of Xanthomonas species and Stenotrophomonas maltophilia. FEMS Microbiol Lett 151, 145-153.

Mougel, C., Thioulouse, J., Perrière, G. \& Nesme, X. (2002). A mathematical method for determining genome divergence and species delineation using AFLP. Int J Syst Evol Microbiol 52, 573-586.

Nei, M. \& Gojobori, T. (1986). Simple methods for estimating the numbers of synonymous and nonsynonymous nucleotide substitutions. Mol Biol Evol 3, 418-426.

Nesme, X., Vaneechoutte, M., Orso, S., Hoste, B. \& Swings, J. (1995). Diversity and genetic relatedness within genera Xanthomonas and Stenotrophomonas using restriction endonuclease site differences of PCR-amplified 16S rRNA gene. Syst Appl Microbiol 18, 127-135.

On, S. L. W., Harrington, C. S. \& Atabay, H. I. (2003). Differentiation of Arcobacter species by numerical analysis of AFLP profiles and description of a novel Arcobacter from pig abortions and turkey faeces. J Appl Microbiol 95, 1096-1105.

Paradis, E. (2006). Analysis of Phylogenetics and Evolution with R. New York: Springer.

Patel, M. K., Kulkarni, Y. S. \& Moniz, L. (1948a). Pseudomonas mangiferae-indicae, pathogenic on mango. Indian Phytopathol 1, 147152.

Patel, M. K., Moniz, L. \& Kulkarni, Y. S. (1948b). A new bacterial disease of Mangifera indica L. Curr Sci 6, 189-190.

Portier, P., Fischer-Le Saux, M., Mougel, C., Lerondelle, C., Chapulliot, D., Thioulouse, J. \& Nesme, X. (2006). Identification of genomic species in Agrobacterium biovar 1 by AFLP genomic markers. Appl Environ Microbiol 72, 7123-7131.

Rademaker, J. L. W., Hoste, B., Louws, F. J., Kersters, K., Swings, J., Vauterin, L., Vauterin, P. \& De Bruijn, F. J. (2000). Comparison of AFLP and rep-PCR genomic fingerprinting with DNA-DNA homology studies: Xanthomonas as a model system. Int J Syst Evol Microbiol 50, 665-677.

Rademaker, J. L. W., Louws, F. J., Schultz, M. H., Rossbach, U., Vauterin, L., Swings, J. \& De Bruijn, F. J. (2005). A comprehensive species to strain taxonomic framework for Xanthomonas. Phytopathology 95, 1098-1111.

Richter, D., Postic, D., Sertour, N., Livey, I., Matuschka, F. R. \& Baranton, G. (2006). Delineation of Borrelia burgdorferi sensu lato species by multilocus sequence analysis and confirmation of the delineation of Borrelia spielmanii sp. nov. Int J Syst Evol Microbiol 56, 873-881.

Robbs, C. F., Ribeiro, R. D. L. D. \& Kimura, O. (1974). Sobre a posicao taxonomica de Pseudomonas mangiferaeindicae Patel et al. 1948, agente causal da "mancha bacteriana" das folhas da mangueira (Mangifera indica L.). Arq Univ Fed Rur Rio de Janeiro 4, 11-14 (in Portuguese).
Rott, P., Chatenet, M., Granier, M. \& Baudin, P. (1988). L'échaudure des feuilles de canne à sucre provoquée par Xanthomonas albilineans (Ashby) Dowson. II. Diagnostic et spectres d'hôtes de l'agent pathogène en Afrique tropicale. Agron Trop 43, 244-251 (in French).

Roumagnac, P., Gagnevin, L., Gardan, L., Sutra, L., Manceau, C., Dickstein, E. R., Jones, J. B., Rott, P. \& Pruvost, O. (2004). Polyphasic characterization of xanthomonads isolated from onion, garlic and Welsh onion (Allium spp.) and their relatedness to different Xanthomonas species. Int J Syst Evol Microbiol 54, 15-24.

Rozas, J., Sanchez-Del Barrio, J. C., Messeguer, X. \& Rozas, R. (2003). DnaSP, DNA polymorphism analyses by the coalescent and other methods. Bioinformatics 19, 2496-2497.

Saitou, N. \& Nei, M. (1987). The neighbor-joining method: a new method for reconstructing phylogenetic trees. Mol Biol Evol 4, 406425.

Schaad, N. W., Postnikova, E., Lacy, G. H., Sechler, A., Agarkova, I., Stromberg, P. E., Stromberg, V. K. \& Vidaver, A. K. (2005). Reclassification of Xanthomonas campestris pv. citri (ex Hasse 1915) Dye 1978 forms A, B/C/D, and E as X. smithii subsp. citri (ex Hasse) sp. nov. nom. rev. comb. nov., $X$. fuscans subsp. aurantifolii (ex Gabriel 1989) sp. nov. nom. rev. comb. nov., and X. alfalfae subsp. citrumelo (ex Riker and Jones) Gabriel et al., 1989 sp. nov. nom. rev. comb. nov.; X. campestris pv. malvacearum (ex Smith 1901) Dye 1978 as $X$. smithii subsp. smithii nov. comb. nov. nom. nov.; X. campestris pv. alfalfae (ex Riker and Jones, 1935) Dye 1978 as X. alfalfae subsp. alfalfae (ex Riker et al., 1935) sp. nov. nom. rev.; and "var. fuscans" of X. campestris pv. phaseoli (ex Smith, 1987) Dye 1978 as X. fuscans subsp. fuscans sp. nov. Syst Appl Microbiol 28, 494-518.

Schaad, N. W., Postnikova, E., Lacy, G. H., Sechler, A., Agarkova, I., Stromberg, P. E., Stromberg, V. K. \& Vidaver, A. K. (2006). Emended classification of xanthomonad pathogens on citrus. Syst Appl Microbiol 29, 690-695.

Schaad, N. W., Postnikova, E., Lacy, G. H., Sechler, A., Agarkova, I., Stromberg, P. E., Stromberg, V. K. \& Vidaver, A. K. (2007). Xanthomonas alfalfae sp. nov., nom. rev. and others. In List of New Names and New Combinations Previously Effectively, but not Validly, Published, Validation List no. 115. Int J Syst Evol Microbiol 57, 893897.

Shimodaira, M. \& Hasegawa, M. (1999). Multiple comparisons of log-likelihoods with applications to phylogenetic inference. Mol Biol Evol 16, 1114-1116.

Stackebrandt, E., Frederiksen, W., Garrity, G. M., Grimont, P. A. D., Kämpfer, P., Maiden, M. C. J., Nesme, X., Rosselló-Mora, R., Swings, J. \& other authors (2002). Report of the ad hoc committee for the re-evaluation of the species definition in bacteriology. Int $J$ Syst Evol Microbiol 52, 1043-1047.

Swings, J. G. \& Civerolo, E. L. (editors) (1993). Xanthomonas. London: Chapman \& Hall.

Tajima, F. (1989). Statistical method for testing the neutral mutation hypothesis by DNA polymorphism. Genetics 123, 585-595.

Thompson, J. D., Gibson, T. J., Plewniak, F., Jeanmougin, F. \& Higgins, D. G. (1997). The CLUSTAL_X windows interface: flexible strategies for multiple sequence alignment aided by quality analysis tools. Nucleic Acids Res 25, 4876-4882.

Thompson, F. L., Li, Y., Gomez-Gil, B., Thompson, C. C., Hoste, B., Vandemeulebroecke, K., Rupp, G. S., Pereira, A., De Bem, M. M. \& other authors (2003). Vibrio neptunius sp. nov., Vibrio brasiliensis sp. nov. and Vibrio xuii sp. nov., isolated from the marine aquaculture environment (bivalves, fish, rotifers and shrimps). Int J Syst Evol Microbiol 53, 245-252.

Trébaol, G., Gardan, L., Manceau, C., Tanguy, J. L., Tirilly, Y. \& Boury, S. (2000). Genomic and phenotypic characterization of Xanthomonas cynarae: a new species causing bacterial bract spot of 
artichoke (Cynara scolymus L.). Int J Syst Evol Microbiol 50, 14711478.

Vauterin, L., Hoste, B., Kersters, K. \& Swings, J. (1995). Reclassification of Xanthomonas. Int J Syst Bacteriol 45, 472-489.

Wayne, L. G., Brenner, D. J., Colwell, R. R., Grimont, P. A. D., Kandler, O., Krichevsky, M. I., Moore, L. H., Moore, W. E. C., Murray, R. G. E. \& other authors (1987). International Committee on Systematic Bacteriology. Report of the ad hoc committee on reconciliation of approaches to bacterial systematics. Int J Syst Bacteriol 37, 463-464.

Young, J. M., Takikawa, Y., Gardan, L. \& Stead, D. E. (1992). Changing concepts in the taxonomy of plant pathogenic bacteria. Annu Rev Phytopathol 30, 67-105. 